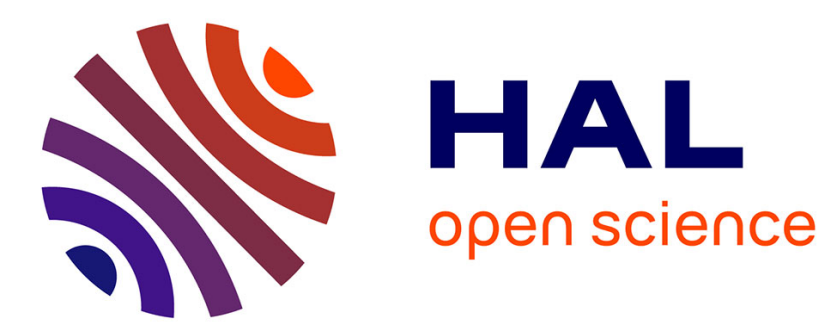

\title{
Hydrogen infrastructure: data-center supply-refueling station synergy
}

Marwa Haddad, Jean Nicod, Marie Péra

\section{To cite this version:}

Marwa Haddad, Jean Nicod, Marie Péra. Hydrogen infrastructure: data-center supply-refueling station synergy. Vehicle Power and Propulsion Conference, Dec 2017, Belfort, France. hal-02392527

\section{HAL Id: hal-02392527 \\ https://hal.science/hal-02392527}

Submitted on 4 Dec 2019

HAL is a multi-disciplinary open access archive for the deposit and dissemination of scientific research documents, whether they are published or not. The documents may come from teaching and research institutions in France or abroad, or from public or private research centers.
L'archive ouverte pluridisciplinaire HAL, est destinée au dépôt et à la diffusion de documents scientifiques de niveau recherche, publiés ou non, émanant des établissements d'enseignement et de recherche français ou étrangers, des laboratoires publics ou privés. 


\title{
Hydrogen infrastructure: data-center supply-refueling station synergy
}

\author{
Marwa Haddad ${ }^{a, b}$, Jean-Marc Nicod ${ }^{a, b}$ and Marie-Cécile Péra ${ }^{a, b}$ \\ ${ }^{a}$ FEMTO-ST Institute, Université Bourgogne Franche-Comté / CNRS / ENSMM / UTBM \\ F-25000 Besançon, FRANCE \\ ${ }^{b}$ FCLAB, FR 3538, Université Bourgogne Franche-Comté / CNRS, \\ rue Thierry Mieg, F-90010 Belfort, FRANCE. \\ [Marwa.Haddad|Jean-Marc.Nicod|Marie-Cecile.Pera] efemto-st.fr
}

\begin{abstract}
Nowadays, data-center are available in a lot of cities in different countries around the world. Their continuous growth in size and complexity due to the increasing demand for storage, networking and computation has become a world wide energetic problem. Taking into account their huge consumption of electricity and the amount of carbon emission in the air, researchers work on making data-centers as green as possible using renewable energy sources. On the other hand, electrical cars, more and more common as they have the potential to provide a high autonomy and to reduce significantly the emmissions that contribute to climate change. These green cars have however an inconvenient which is the availability of hydrogen station to fill their tank. Thus, this paper presents first a sizing of a hybrid system to power a data-center of $500 \mathrm{~kW}$ composed of photovoltaic panels, winding turbines, batteries and fuel cells. Consequently, this paper presents an option for this hydrogen storage to become easily a secure hydrogen station to supply fuel cell cars. Our contribution consists then in finding the accurate sizing (wind turbines, solar panels as primary sources, hydrogen as a long term storage and batteries as a back up) for both data centers and fuel cell vehicles.
\end{abstract}

\section{INTRODUCTION}

Nowadays, everybody accesses daily to public or personalized services on Internet. Thus, we can reach our bank, health insurance accounts, plan an agenda in a very transparent way and link it to the emails, we are able to share music, online photos and to communicate directly by using social networks. This space, in which we transparently navigate, is named "the Cloud". The Cloud then offers remote access to all of these spaces from different resources such as phones, tablets or computers. Thereby, the loss of a phone no longer rhymes with the loss of the address book.

Getting the possibility to connect to our email address and to check all the rest of data means that these emails are memorized somewhere on one hard disk accessible at any time into a real data-center. Indeed, there is diverse resources that receive our requests and provide us with the content of the data that we want to access. This supposes complex network connections to route the information and deal with conflict problems. These devices which were mainly deployed at the level of companies' resources a few years ago, are now clustered together in what we call a data-center.

The vast growth of internet and the increase of the number of online services have highlighted the cost imposed by the
Cloud in general and by data-centers in particular at the energy consumption level. Indeed each of our stored e-mails runs permanently on one hard disk. Moreover any request to any online service, search engine, data consultation needs a particular processing. Thus using the Internet consumes electricity. According to the Environment and Energy Control Agency, sending an e-mail with a file as an attachment requires the cost of operating a high-powered bulb for one hour. Every day, 10 billion emails are sent around the world, which corresponds on average to $50 G W h$, means the electrical production of $15 \mathrm{nu}$ clear power stations operating for one hour [1]. Consequently, the global electricity part dedicated to their consumption has reached unprecedented levels. According to the estimates of the year 2010, data-centers consumed roughly $1.5 \%$ of the total electricity used in the world within the half attributed to cooling [2]. This electricity consumption influences on climate change as most of the electricity is produced from fossil fuels. A 2008 study has estimated that data-centers around the world emitted 116 million tons of carbon, a little more than what Nigeria emitted in the same year [3]. The cost of electricity is therefore a significant burden on data-center operators, which has led to many green energy initiatives.

One of these initiatives is to allow a data-center either to generate its own renewable energy or to use power directly from the nearest renewable power plant. Several recent initiatives are proposed in that end. For example, McGrawHill has recently completed a $14 M W$ solar field for its data-center [4] and Apple build a $40 M W$ solar field for its North Carolina data-center [5]. Nevertheless, many researchers investigate in the same course and try to combine renewable energy sources to supply their data-centers: the European project named "GreenDataNet" combines solar panels and batteries, has designed and validated a new smart energy management system allowing urban data-centers to radically improve their energy performance [6]; the "Renew it" project aims at developing a simulation tool to evaluate the energy performance of different technical solutions integrating diverse renewable energy sources as wind turbines and photovoltaics in different European climate regions [7].

Moreover, the DATAZERO project 1 funded by the French

\footnotetext{
${ }^{1}$ http://www.datazero.org
} 
National Research Agency (ANR), project of which we are engaged, aims at building an innovative adaptive data-center concept that optimizes both IT and power loads. Relying on the latest technologies in terms of renewable power sources, electrical equipment, servers and cloud management systems, it aims at drastically reducing the carbon impact of the energy consumption of tomorrow's data-centers. Thus, we argued that an option design for green data-centers is to supply them with both solar/wind energy sources and fuel cells. Batteries are also essential to assure a backup function. The major research challenge with solar and wind power is that they are intermittent sources, so they are not always available. For example, the wind turbines work following the wind speed. In case the minimal wind speed is less than $15 \mathrm{~km} / \mathrm{h}$, a turbine cannot be activated to produce electricity and in case it's more than $90 \mathrm{~km} / \mathrm{h}$, a device voluntarily stops the turbine for security reasons [8]. Then, the sizing of the storage of the data-center represents a big challenge for that kind of data-center. The second challenge consists in sizing the hydrogen so it can supply both data-centers as a back-up generator in time of need and fuel cell cars as a fuel cell station.

In fact, in 2012, the number of data-center worldwide was estimated at 509,147 [9] and it will continue growing until it peaks at 8.6 million in 2017 with a total area of more than 186 million square meters almost the equivalent of more than 25,100 football fields, according to the recent report published by IDC [10]. Thus, these data-centers could effectively be an hydrogen station for fuel cell cars with the appropriate sizing.

Thus in this paper, we will explain the methodology used to dimension the renewable energy sources used within the DATAZERO project, to power a data center of $500 \mathrm{~kW}$. In particular, we are designing an first approach to make a sizing of this hybrid system. Moreover, it explains how datacenters could be a supplier for these FCV in the future if the dimensioning is more or less over sized.

\section{DATA-CENTER}

\section{A. Presentation}

A data-center is a set of resources that houses all manner of IT equipment, including servers, storage subsystems, networking switches, routers and firewalls, as well as the cabling and physical racks used to organize and interconnect the IT equipment. Diverse requests of different natures are addressed to a data-center ranging from consultation of information to the triggering of treatment more or less important as the daily treatments or SaaS type calculations. That's why these datacenters has to maintain a high level of security.

\section{B. Power distribution model}

The data-center energy distribution system is the equipment responsible for supplying electrical energy to the load of the system (computer and mechanical equipment). Taking in consideration the micro-breaks or longer outages that the public grid may have, it can cause a dis-function of a data-center. Thus, it is essential to ensure adequate power supply. This equipment must therefore meet the required energy quality and security of supply. Figure 1 shows a diagram of a power infrastructure of a standard data-center.

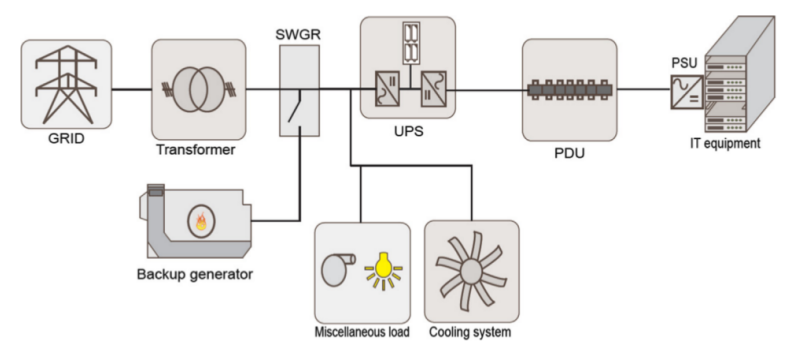

Fig. 1. Electric System Distribution of a data-center (source: [11])

\section{Implementation of renewable energy on data-centers}

Data-centers are important energy consumers, consequently Renewable Energy Sources (RES) can play an important role in this industry. Researches on RES and their applications to different fields has attracted a great interest for many researchers around the world. To give arguments of the integration of renewable energy sources into real systems, Dalton et al. conducted technical and financial analysis of the RES-only and grid/RES hybrid power supply configurations for a large hotel connected to the grid [12]. Recently, researchers are more interested in using RES to provide some of the overall energy consumption of data-centers. However, while renewable energies are available intermittently, the computation demands for data-centers has to be satisfied even when green energy is not available.

Other companies used fuel cells as a building's primary source of power, using the local grid as back-up power if needed. In addition, the excess heat generated by fuel cells can be used to provide cooling for the IT rooms. For example, EBAY operates $6 M W$ of fuel cells powering its South Jordan, Utah data-center [13] and Apple has installed $10 \mathrm{MW}$ of fuel cells coupled with solar panels to power its Maiden, North Carolina iCloud data-center [14]. The rub is that fuel cells are expensive, depending on local markets. They can produce electricity at a cost higher than grid power, which does not make economical sense for a data-center. In this situation, data-centers use brown energy drawn from the grid and emit carbon in the environment.

\section{MODEL OF HYBRID SYSTEM COMPONENTS}

The hybrid power system composed of solar panels (PV), wind turbines (WT), fuel cells (FC), batteries, electrolyzer, hydrogen tank and other energy conversion devices is a bit complicated. In order to analyze and size correctly the introduced hybrid system, it is necessary to understand the model of each component. As a result, we can obtain the energy relationships between various components. 
TABLE I

PV PANEL PARAMETERS

\begin{tabular}{|l|l|}
\hline Maximum power & 265 \\
\hline Efficiency & $16.3 \%$ \\
\hline Size & 1.65 \\
\hline
\end{tabular}

\section{A. Photovoltaic panel}

The relation between the irradiation data and output power of the PV panels could be described as the following equation (1):

$$
P_{p v}=I \times A_{p v} \times \eta_{p v}
$$

where, $I$ is the hourly solar irradiance in $k W / m^{2}, A_{p v}$ is the area of the PV panel in $m^{2}$ and $\eta_{p v}$ is PV panels' efficiency. For our study, we choose the performance of an IBC PolySol 265 CS4 $(265 W)$ solar panel as provided in Table I

\section{B. Wind Turbine Generator}

The model for the output power of one wind turbine generator follows the power curve shown in Figure 2. So, the turbine starts generating power at the cut-in wind speed $V_{c i}$. Then, the generated output power increases with the increases of wind speed from the cut-in $V_{c i}$ to the rated wind speed $V_{r}$. When the wind speed varies between the rated wind and the cut-out wind speed $V_{c o}$, which is the maximum wind speed value at which the turbine can correctly work, the turbine produces a constant or rated power. Once the wind speed goes beyond the cut-out speed, the turbine stops generating for safety reasons.

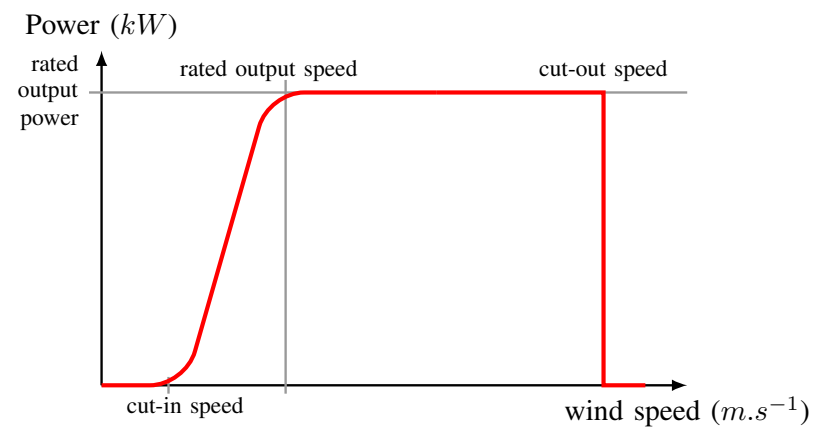

Fig. 2. Ideal wind turbine power output

The mathematical model of this behavior is as follows the equation (2):

$$
P_{w}=\left\{\begin{array}{rrr}
0 & \text { if } & v(t) \leq v_{c i} \text { or } v(t) \geq v_{c o} \\
P_{r} \frac{v^{3}(t)-v_{c i}^{3}}{v_{r}^{3}-v_{c i}^{3}} \text { if } & v_{c i}<v(t)<v_{r} \\
P_{r} \text { if } & v_{r}<v(t)<v_{c o}
\end{array}\right.
$$

where $v(t)$ is the wind speed $\left(m . s^{-1}\right)$ at any time $t(s)$.

The total power output of the wind turbine generator at an hour $t$ is given by the equation (3):

$$
P_{w t}=P_{w} \times A_{w} \times \eta_{w}
$$

where $A_{w}$ is the total swept area by the blades and $\eta_{w}$ is the efficiency of the wind turbine. Different wind turbines have diverse power output and performance curves. Therefore, the modeling equation of a wind system is strongly influenced by the power curve of the wind turbine that is used. For our study, we choose the parameters given in Table II

TABLE II

WIND TURBINE GENERATOR PARAMETERS

\begin{tabular}{|l|l|}
\hline Rated power & $800 \mathrm{~kW}$ \\
\hline cut-in speed & $3.5 \mathrm{~m} . \mathrm{s}^{-1}$ \\
\hline rated speed & $12 \mathrm{~m} . \mathrm{s}^{-1}$ \\
\hline cut-out speed & $28 \mathrm{~m} . \mathrm{s}^{-1}$ \\
\hline Swept area & $1810 \mathrm{~m}^{2}$ \\
\hline
\end{tabular}

Above all, the energy generated in one hour is given as follows:

$$
P_{t o t}=P_{p v}+P_{w t}
$$

\section{Hydrogen System}

The hydrogen system is composed of electrolyzer, fuel cell and hydrogen tank. Taking into account the limitation of the batteries, the over production of electrical energy (when batteries are full), the electrolyzer could transform the difference to dihydrogen molecules and store them into tanks so there is no waste. This process is explained by the following chemical reaction (5):

$$
\mathrm{H}_{2} \mathrm{O} \rightarrow \mathrm{H}_{2}+\frac{1}{2} \mathrm{O}_{2}
$$

In order to raise density of stored energy, a compressor may pressurize electrolyzer's output up to 200 bar [15]. Then, the power from electrolyzer to hydrogen is expressed as follows:

$$
P_{\text {tank }}=P_{\text {diff }} \times \eta_{\text {el }}
$$

where $\eta_{e l}$ is the electrolyzer efficiency which assumed as a constant. $P_{\text {tank }}$ is the transferred power from the electrolyzer to the tank and $P_{\text {diff }}$ is the transferred power from generated power to the electrolyzer.

To realize the same reaction in the other sense, producing electrical energy from hydrogen, we can use a fuel cell. The chemical reactions at each cathode are the following:

- Anode reaction: $H_{2} \rightarrow 2 H^{+}+2 e^{-}$

- Cathode reaction: $\frac{1}{2} \mathrm{O}_{2}+2 \mathrm{H}^{+}+2 e^{-} \rightarrow \mathrm{H}_{2} \mathrm{O}$

Under given working conditions, 1 mole of hydrogen is equivalent to $2.10^{3} \mathrm{~kg}$ equal to $241.8 \mathrm{~kJ}$. To be more specific: $1 \mathrm{~kg}_{\text {hydrogen }}=120.910^{3} \mathrm{~kJ}=33.6 \mathrm{kWh}$

The converted energy can be calculated at any time $t$ as follows:

$$
P_{\text {tank }}=P_{\text {diff }} \times \eta_{e l} \times \eta_{f c}
$$

where $\eta_{f c}$ is the efficiency of the fuel cell. 


\section{Sizing StRAtegy}

In this paper, the sizing of the hybrid system operates as the following strategy:

1) Calculation of the needed energy demand during 1 year of the data-center and for a portion of 10 hybrid cars.

2) Calculation of the energy produced from 1 wind turbine during 1 year.

3) Calculation of the energy produced from 1 photovoltaic panel during 1 year.

4) Calculation of number of WT and PV that we need.

5) Calculation of the energy difference between generated and needed.

6) Conversion of the energy difference to a volume of hydrogen.

7) Calculation of number of tank.

We propose in this paper to dimension the infrastructure as an iterative process. At the beginning, we start by using the maximum of $n$ wind turbines and completing the difference needed with photovoltaic panels. Then, we use $(n-1)$ wind turbines and complete panels till we are able to reach the power demand with only using photovoltaic modules.

\section{A. Calculation of the needed energy}

The task of this paper is to find a sizing of system components to power a data-center of $500 \mathrm{~kW}$ and to be in the same time a station for hybrid cars. Thus, we supposed that the data-center needs $500 \mathrm{~kW}$ each hour during one year. Then the energy needed over one year is calculated in the following equation (8):

$$
D 1=P_{\text {datacenter }} \times 24 \times 365=4380000 \mathrm{kWh}
$$

We assume that a hybrid cars consumes around $0.76 \mathrm{~kg}$ of hydrogen to travel $100 \mathrm{~km}$ [16]. If we suppose that every cars travels $31 \mathrm{~km}$ on average per day [17], their consumption in hydrogen in $(\mathrm{kg})$ for one year is given by $C$ in the following formula:

$$
C=\frac{31 \times 0.76}{100} \times 10 \times 365=875 \mathrm{~kg}
$$

This quantity of hydrogen corresponds to an electrical energy value $29433.6 \mathrm{kWh}$. The total energy needed is then:

$$
D=D 1+C=4409433.6 k W h
$$

\section{B. Calculation of the energy produced}

In calm weather, the idealized daily wind speed distribution can be represented like the typical curve of photovoltaic system. Wind speed is higher during the day (from sunrise to sunset) than during the period after sunset and sunrise. Wind speed follows a sine curve during the day, and it remains constant for periods before sunrise and after sunset [18]. Moreover we assume that the production of energy by the primary sources during one year linearly increases when days get longer and linearly decreases when days get shorter (see Figure 3). In this figure $n$ represents the number days
( $n=365), \max$ and $\min$ are respectively the maximum and minimum production of energy in the year for each day. So 0 or $n$ corresponds to December the 21th (the day with the shortest light) and $n / 2$ to June the 21th (the day with the longest light).

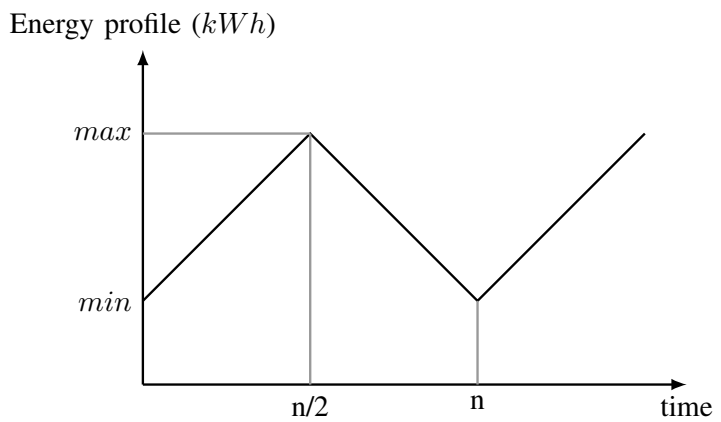

Fig. 3. Primary energy produced by PV and WT

During one year, the electrical production varies greatly over season. With making a zoom on the daily scale, it's obvious to differentiate the best production day (E) and the worst one (e) as showed in Figure 4 and where D is the energy demand of the data-center. Considering our model, the overproduction of one day has to offset the underproduction of another day. And using both the wind turbine and the photovoltaic panel models introduced before, we can estimate their electrical production in $k W h$ during that two days. This allows us to evaluate the primary source sizing. To make this sizing, we choose the worst and the best days ( 0 and $n / 2$ ).

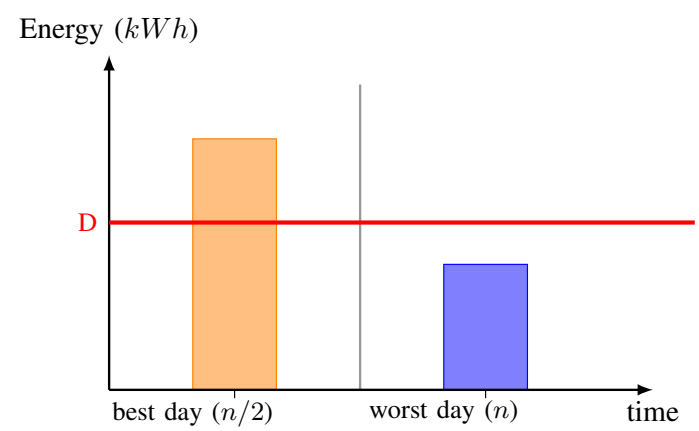

Fig. 4. Primary energy produced by PV and WT

As mention before, the objective fixed is to fulfill the lack of energy of the worst day by the overproduction of the best day and to repeat this operation all over the year by taking into account the storage efficiency $\eta$. This problem is summarized by these equations (11):

$$
\begin{array}{r}
(E-D) \times \eta=D-e \\
E \times \eta-D \times \eta=D-e \\
\eta E+e=D(1+\eta)
\end{array}
$$


We assume the energy produced during the best day $E$ and the energy produced during the worst day $e$ could be written using a proportionality coefficient $\alpha: e=\alpha E$.

$$
\begin{aligned}
\eta E+\alpha E & =D(1+\eta) \\
(\eta+\alpha) E & =D(1+\eta) \\
E & =\frac{D(1+\eta)}{(\eta+\alpha)}
\end{aligned}
$$

Then, the sizing of WT and PV is made following the Power demand that should be provided on the best day. Considering the value of $E$ and the energy model for irradiance and wind, we can found the pic of power that the photovoltaic panels and the wind turbines have capture to produce $E$ at the end of the best day. This power is $P_{\text {demand }}$.

\section{Sizing of $W T$ and $P V$}

Once the electrical production of one WT is fixed, the program proceed to the calculation of the number of wind turbines as given in the following statement $[13$ :

$$
N_{w t}=P_{\text {demand }} / P_{w t}
$$

where $N_{w t}$ is the number of wind turbines, $P_{w t}$ is the power that is observed of the WT when $P_{\text {demand }}$ is received by the wind conditions.

Then, the area of photovoltaics $N_{p v}^{i}$ is given by 14 where $i$ is the number of WT are is chosen:

$$
N_{p v}^{i}=\frac{P_{\text {demand }}-N_{w t}^{i} \times P_{w t}}{P_{p v}}
$$

\section{Calculation of the energy difference}

Taking into account the storage efficiency, the model used in the beginning is not anymore accurate. Actually the real model then representing the system could be defined in Figure 5

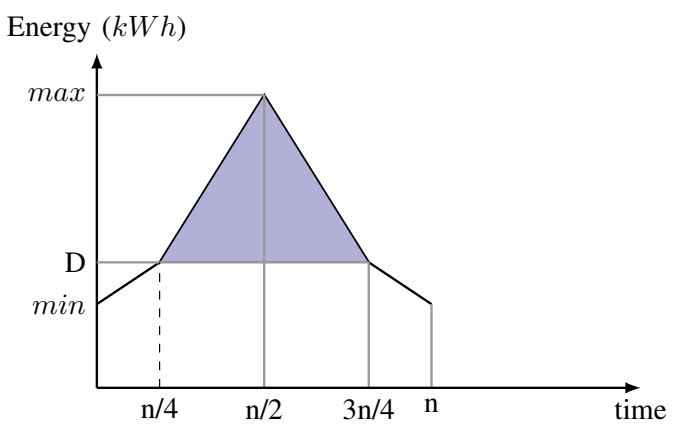

Fig. 5. Primary energy produced by PV and WT

where $\max$ and $\min$ are respectively the maximum and minimum energy produced in a day during the year, $D$ is the power of the data-center and $n=365$ is a year.
To conclude, the energy difference $E_{\text {diff }}$ consists actually of the area of the triangle above the demand and is calculated by (15):

$$
E_{\text {diff }}=\frac{\frac{D \times 24 \times(1+\eta)}{\eta+\alpha} \times \frac{n}{2}}{2}
$$

\section{E. Conversion of the energy difference to a volume of $\mathrm{H}_{2}$}

To convert, in an easy way, an electrical energy to a mass or a volume of hydrogen, these steps should be followed. In a first time, use the enthalpy of $\mathrm{H}_{2}$ in its lowest value (when dihydrogen is gas) (16:

$$
\begin{array}{r}
\Delta H=241.8 \mathrm{~kJ} / \mathrm{mol} \\
1 \mathrm{~mol} \leftrightarrow 2.10^{-3} \mathrm{~kg} \leftrightarrow 241.8 \mathrm{~kJ} \\
1 \mathrm{~kg}=\frac{241.8}{210^{-3}}=120.9 \mathrm{~kJ}
\end{array}
$$

To convert it in $k W h$, more used in the electrical language:

$$
1 \mathrm{~kg}=\frac{120.9}{3600}=33.6 \mathrm{kWh}
$$

In the end, to transform it in a volume using the unit normolitre:

$$
\begin{array}{r}
1 \mathrm{~mol} \leftrightarrow 2.10^{-3} \mathrm{~kg} \leftrightarrow 22.4 \mathrm{Nl} \\
1 \mathrm{~kg}=\frac{22.4}{210^{-3}}=11.210^{3} \mathrm{Nl}=11.2 \mathrm{Nm}^{3}
\end{array}
$$

To conclude, the conversion in the program is executed following this expression (19):

$$
V=\frac{E_{\text {diff }} \times \eta_{e l} \times \eta_{f c} \times 11.2}{33.6}
$$

where $V$ is the volume of dihydrogen in $N m^{3}, E_{\text {diff }}$ is the energy difference between generated and demand and $\eta_{e l}, \eta_{f c}$ are respectively the efficiency of the electrolyzer and the fuel cell.

\section{RESUlts}

In order to perform the sizing methodology, results are performed using input data profiles. Solar radiations are obtained from PVGis, an online free solar photovoltaic energy calculator for stand alone or connected to the grid PV systems and plants, in Europe and the load from the instruction of the DATAZERO project.

When we use the calculation described before, we obtain only 5 possible cases as detailed in Table III.

TABLE III

ELECTRICAL DEVICE AND STORAGE SIZING FOR THE 5 CASES

\begin{tabular}{|l|c|c|c|c|c|}
\hline & Case 1 & Case 2 & Case 3 & Case 4 & Case 5 \\
\hline Number of WT & 4 & 3 & 2 & 1 & 0 \\
\hline PV Area ${ }^{2}$ & 0 & 8960 & 22160 & 35359 & 48559 \\
\hline $\begin{array}{l}\text { The volume of } \\
\text { hydrogen }\left[\mathrm{Nm}^{3}\right]\end{array}$ & 120335 & 120335 & 120335 & 120335 & 120335 \\
\hline
\end{tabular}

These results represent a first simple sizing which seems efficient for powering the data-center and a range of 10 hybrid cars per day during a year. As represented in Table [III, the 
volume of hydrogen does not change following the change of the primary sources.

Actually the results of wind Turbines and Photovoltaics are drawn in Figure 6

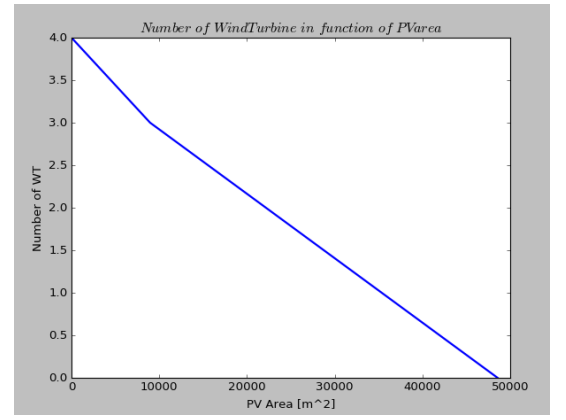

Fig. 6. Number of Wind Turbines in function of PV area

\section{CONCLUSION}

In this paper, we have proposed a first sizing for the hybrid system powering the new data-center DATAZERO. The sizing was precise for the primary sources composed of photovoltaics and wind turbines. We calculated the energy needed to the data-center and a range of 10 hybrid cars by using an iterative process that calculates the number of wind turbines and PV area needed in each case.

The objective was also to size in an accurate way the storage part composed of batteries and fuel cells. In this paper, the batteries were supposed existing and our focus was on the hydrogen system. Perspectives is now to focus on sizing of fuel cells, electrolyzer needed, batteries, etc.

To conclude, by presenting an over sizing of the primary sources and hydrogen tank, we explain how data-centers all over the world can help in the development of FCV by being their gas stations.

\section{ACKNOWLEDGMENT}

This work was supported in part by the ANR DATAZERO (contract "ANR-15-CE25-0012") project and by the Labex ACTION project (contract “ANR-11-LA BX-01-01”).

\section{REFERENCES}

[1] C. Tison and L. Lichenstein, "Internet : la pollution cachée," https: //www.youtube.com/watch?v=75mx9pRJyLg\&t=1402s, oct 2016, Camicas producted conjointly with France Télévision.

[2] J. Koomey, "Growth in data center electricity use 2005 to 2010," A report by Analytical Press, completed at the request of The New York Times, vol. 9, 2011.

[3] J. Mankoff, R. Kravets, and E. Blevis, "Some computer science issues in creating a sustainable world," Computer, vol. 41, no. 8, pp. 102-105, Aug. 2008. [Online]. Available: http://dx.doi.org/10.1109/MC.2008.307

[4] R. Miller, "Huge solar array will support nj data center," datacenterknowledge, 2011, http://www.datacenterknowledge.com/archives/2011/ 06/14/huge-solar-array-will-support-nj-data-center/

[5] Apple, "Apple facilities, environmental footprint report," Apple and the Environment, 2013. [Online]. Available: http://www.apple.com/ environment/

[6] "Green data net project," 2016, http://www.greendatanet-project.eu/ home.html

[7] "Renewit project," 2016, http://www.renewit-project.eu/
[8] "Pourquoi les éoliennes sont-elles parfois arrêtées alors que le vent souffle?" http://www.connaissancedesenergies.org/ pourquoi-les-eoliennes-sont-elles-parfois-arretees-alors-que-le-vent-souffle July 2011.

[9] J. Glanz, "Power, Pollution and the Internet," The New York Times, 2012.

[10] v. p. o. I. Richard Villars, http:// hebergement-et-infrastructure.fr/actualites-et-innovations/ 8-6-millions-de-datacenters-dans-le-monde-en-2017 Accessed online in Sept 2017.

[11] Í. Goiri, M. E. Haque, K. Le, R. Beauchea, T. D. Nguyen, J. Guitart, J. Torres, and R. Bianchini, "Matching renewable energy supply and demand in green datacenters," Ad Hoc Networks, vol. 25, pp. 520-534, 2015.

[12] G. Dalton, D. Lockington, and T. Baldock, "Feasibility analysis of renewable energy supply options for a grid-connected large hotel," Renewable energy, vol. 34, no. 4, pp. 955-964, 2009.

[13] S. Curtin and J. Gangi, "The business case for fuel cells reliability, resiliency \& savings," fuel cells 2000, vol. 36, 2013.

[14] F. C. . H. E. Association, "Fuel cells and data center," vol. 1, 2013.

[15] R. S. Garcia and D. Weisser, "A wind-diesel system with hydrogen storage: Joint optimisation of design and dispatch," Renewable energy, vol. 31, no. 14, pp. 2296-2320, 2006.

[16] Toyota, http://www.automobile-propre.com/voitures/toyota-mirai// Accessed online in sept 2017.

[17] P. Philippe, http://www.newsroom-publicismedia.fr/ 31-kms-parcourus-en-moyenne-par-jour-par-une-voiture/

[18] M. Marinelli, P. Maule, A. N. Hahmann, O. Gehrke, P. B. Nørgrd, and N. A. Cutululis, "Wind and photovoltaic large-scale regional models for hourly production evaluation," IEEE Transactions on Sustainable Energy, vol. 6, no. 3, pp. 916-923, 2015. 